\title{
DE ACCOUNTANT EN DE KLEINE ONDERNEMING
}

\author{
door P. J. H. J. Bos
}

"De accountant en de kleine onderneming" was een der door het Congres-comité voorgestelde onderwerpen, waaruit een keuze moest worden gemaakt voor de behandeling op het Internationaal Accountantscongres 1957. Na het overleg met de buitenlandse zusterorganisaties is besloten dit onderwerp niet op het Congres te behandelen. Daar echter wel gebleken is, dat zowel in Nederland als in het buitenland voor dit onderwerp belangstelling bestaat, heeft de redactie van dit maandblad mij, als ex-voorzitter van de voor dit onderwerp in het leven geroepen sub-commissie, verzocht hierover een artikel te publiceren.

$\mathrm{Na}$ enige aarzeling heb ik gemeend aan dit verzoek te moeten voldoen; ik wijs er echter op dat dit artikel uitsluitend bedoeld is om een onderlinge gedachtenwisseling te stimuleren. De tijd heeft mij ontbroken mij te oriënteren omtrent hetgeen over dit onderwerp in het buitenland is gepubliceerd; voorts heb ik persoonlijk te weinig ervaring op dit terrein om alle aspecten van dit vraagstuk en de in de praktijk gebleken moeilijkheden te overzien. Daar voorts de bespreking in de genoemde sub-commissie niet verder gegaan is dan nodig was om tot een probleemstelling te komen, geeft het onderstaande uitsluitend mijn, uiteraard subjectieve, mening weer.

Ik heb de genoemde probleemstelling, zoals deze na overleg met het congres-comité was vastgesteld, als uitgangspunt genomen. Voor de beantwoording van de in deze probleemstelling aan de orde gestelde vragen heb ik mij uitsluitend gebaseerd op de in Nederland bestaande verhoudingen. Daar uiteraard een tijdschriftartikel niet te omvangrijk mag zijn, heb ik volstaan met een korte algemene beschouwing en getracht ten aanzien van de in de probleemstelling genoemde punten mijn mening summier weer te geven. Hoewel mij bekend is dat ten aanzien van een aantal der in dit artikel ter sprake gebrachte problemen nog verschil van mening heerst en de problemen ook vanuit een andere visie kunnen worden benaderd, heb ik zoveel mogelijk afgezien van een polemische behandeling. Daar mijn eigen mening ten aanzien van enkele der in de probleemstelling aan de orde gestelde problemen nog niet voldoende gevestigd is, spreek ik de hoop uit dat deze publicatie de collega's, die een afwijkende mening hebben, er toe moge brengen van deze mening te doen blijken.

\section{A. Inleiding.}

Gegeven het onderwerp zal ik mij uitsluitend beperken tot de opdrachten, welke door kleine ondernemingen worden gegeven aan public accountants. Deze opdrachten kunnen zowel betrekking hebben op een bedrijfseconomisch advies als op een bedrijfseconomisch oordeel. Summier aangegeven kan gesteld worden, dat de accountant zich heeft te beraden:

a. of de opdracht kan worden aanvaard;

b. welke contrôlewerkzaamheden moeten worden verricht om tot een verantwoord advies resp. oordeel te komen.

Voor het verband tussen de functie, de taak en de verantwoordelijkheid van de accountant sluit ik aan bij het door Prof. Limperg in „,De Leer van het gewekte vertrouwen" gestelde. "T.a.v. de door de accountant te verrichten werkzaamheden releveer $i k$, in verband met het onderwerp van dit 
artikel, hieruit: ,dat elke contrőle ,,volkomen” moet zijn, d.w.z. ze moet een ,,sluitend geheel vormen, doeltreffend voor de vervulling der functie en ,dus voor het gestelde doel, doch ze behoeft daarom nog geenszins alle ",gebeurtenissen, alle feiten, alle boekingen, alle gegevens te bestrijken; ze ,,behoeft dus niet „volledig" te zijn."

T.a.v. de vraag of de opdracht kan worden aanvaard wijs ik er op, dat dit alleen mogelijk is, als verwacht mag worden dat het gestelde doel kan worden bereikt. In dit verband zij mede gereleveerd de opmerking van Prof. Limperg: ,dat elke beperking der functie bij de alge,mene contrôle uitgesloten is en voorts dat deze algemeen verworpen ,, beperking der functie niets heeft uit te staan met die beperkingen van "de taak, welke de functie onaangetast laten."

Voorts zij er op gewezen dat uiteraard de kosten der contrôle vooral voor de kleine onderneming relatief zeer hoog kunnen worden en in een aantal gevallen de contrôle hierdoor economisch niet verantwoord kan zijn.

Algemeen aanvaard wordt de stelling dat de door de accountant te verrichten werkzaamheden zullen differentiëren naar gelang van de aard der opdracht, de aard van het in de onderneming uitgeoefende bedrijf en naar de omvang van de onderneming. Als reeds aangegeven in de titel van dit artikel zal ik mij beperken tot de invloed van de omvang van de onderneming en meer in het bijzonder nagaan in hoeverre de functie en de taak van de accountant bij de kleine onderneming verschilt resp. bijzondere aspecten vertoont t.o.v. de middelgrote of grote onderneming.

Vooraf dient thans te worden vastgesteld naar welke criteria de indeling naar kleine, middelgrote en grote ondernemingen zal geschieden en welke grenzen hiervoor in acht dienen te worden genomen.

Zoals bekend wordt in de ongevallenstatistiek der Sociale Verzekeringsbank als kleine onderneming beschouwd, de onderneming waarin minder dan 10 ,type-werklieden" werkzaam zijn, waarbij onder type wordt verstaan de werkman met 300 werkdagen per jaar. Het relatieve belang van de volgens dit criterium , kleine ondernemingen" moge blijken uit de volgende cijfers, ontleend aan de gepubliceerde ongevallenstatistiek over 1953.

Aantal ondernemingen Kleinbedrijf ( 1 t.m. 9 werklieden)

$88 \%$ van het geregistreerde aantal ondernemingen.

Aantal type werklieden Kleinbedrijf ( 1 t.m. 9 werklieden)

$17 \%$ van het geregistreerde aantal type werklieden.

In verband met het naast elkaar bestaan van kapitaalintensieve en loonintensieve bedrijven en de invloed van de aard van het bedrijf. meen ik te mogen stellen, dat het bedoelde criterium voor het onderhavige vraagstuk ondoelmatig en zelfs onbruikbaar is. Evenmin vereist motivering, dat de onderscheiding naar kleine, middelgrote- en grote bedrijven niet kan worden afgemeten naar een van de kenmerken „omvang vermogen", „omzet", ,lonen" enz.

Voor het onderhavige onderwerp acht ik een onderscheiding naar de volgende elementen wel doelmatig:

a. in het algemeen naar de mate warin de arbeidsverdeling kan worden doorgevoerd, zonder in strijd te komen met het economisch motief;

b. in het bijzonder naar de onvolkomenheid in de leiding, zoals deze bij een kleine onderneming van nature gegeven is. 
Voor de motivering van het sub a genoemde criterium moge ik hier volstaan met te wijzen op het belang van een goede administratieve organisatie (incl. interne contrôle) voor een rationele vervulling van de accountantsfunctie. Voor zover de interne contrôle niet aan de daaraan te stellen eisen voldoet, zal de mogelijkheid bestaan dat een accountantscontrôle niet tot het gestelde doel kan leiden, respectievelijk aanvullende werkzaamheden vereist, welke dus extra kosten medebrengen.

In dit verband zal ik onder kleine onderneming verstaan een onderneming, waar zonder in strijd te komen met het economisch motief (b.v. door aanstelling van meer personen dan voor wie een volle dagtaak is), de administratieve organisatie (mede omvattende de interne contrôle) niet dusdanig kan worden verbeterd, dat de accountantscontrôle tot een oordeel kan leiden omtrent de juistheid der jaarrekening, of zo dit laat ste nog wel mogelijk zou zijn, de omvang van de door de accountant aanvullend te verrichten werkzaamheden een dusdanige omvang zouden aannemen, dat de kosten der contrōle niet meer verantwoord zouden zijn.

Ter vermijding van misverstand moge ik op de volgende punten wijzen:

1. kenmerkend is niet de bestaande administratieve organisatie (incl. interne contrōle) doch die welke zonder in strijd te komen met het economisch motief, bereikbaar is.

2. het oordeel van de accountant steunt uiteindelijk op twee groepen van, onderling maar ten dele vervangbare, peilers, n.l. het geheel van maatregelen van interne contrôle en het geheel van bevindingen terzake van verrichte werkzaamheden, geraadpleegde stukken, verkregen inlichtingen enz. Het relatieve belang van beide groepen van peilers variëert sterk naar gelang van de aard van het bedrijf.

Handels- en industriële ondernemingen, waar gebruik kan worden gemaakt van de verbandscontrôle zullen, mede afhankelijk van het beschikbare arsenaal van hulpmiddelen als begroting, kostenstandaard enz., veel eerder buiten het bovenomschreven begrip voor ,kleine onderneming" vallen dan b.v. dienstverleningsbedrijven. Ook binnen de groepen van ondernemingen is grote variatie. Zelfs bij handels - en industriële ondernemingen dient de interne contrôle echter aan bepaalde minimumeisen te voldoen. Hoewel ik persoonlijk van mening ben, dat vele handels- en industriële ondernemingen, die naar andere criteria gemeten klein zijn, nog niet onder vorenbedoeld begrip van "kleine onderneming" vallen en dus in principe controleerbaar blijven, acht ik het toch gewenst hier een opmerking te releveren, die ik vroeger in een ander verband reeds heb gemaakt, n.l. dat de verbandscontrôle wel een zeer belangrijk doch geen onfeilbaar contrōlemiddel is. De mate waarin op basis van de verbandscontrôle tot juistheid kan worden geconcludeerd is toch afhankelijk van twee factoren:

a. in hoeverre de juistheid vaststaat van het gegeven, waaraan men het te controleren bedrag toetst.

b. binnen welke grenzen het verhoudingsgetal, hetwelk men als basis neemt, objectief vaststaat.

T.a.v. het tweede kenmerk, n.l. de onvolkomenheid in de leiding, moge ik primair verwijzen naar de centrale plaats, die de leider van het bedrijf inneemt. Voorts wijs ik er op, dat naar gelang een onderneming kleiner 
wordt de ondernemer in mindere mate werkzaamheden kan delegeren aan anderen en minder kan terugvallen op stafemployé's respectievelijk in verband met de kosten, adviezen bij externe deskundigen kan inwinnen. In het prae-advies N.I.v.E. 1953, „Hoe is het mogelijk ... het kleine bedrijf" wordt t.d.a. gezegd:

,dat het kleine bedrijf een eigen problematiek heeft, die zich concen. ,treert in de functie van de ondernemer. De functie van de kleine onder.,nemer, wij zouden hem bijna als duivelskunstenaar willen betitelen, heeft ,zeer speciale kenmerken enis niet te vergelijken met de functie van een "directeur van een groot bedrijf, noch met die van een afdelingschef."

De uiterst veelzijdige taak van de ondernemer in een kleine onderneming brengt dan ook veelal een onvolkomenheid in de leiding mede.

Voor het onderhavige probleem is dit van belang, daar de leider hierdoor in grote mate behoefte zal hebben aan de adviezen van de accountant en in mindere mate in staat zal zijn dit advies zelfstandig te beoordelen. In dit verband moge ik hier verwijzen naar het artikel van Prof. Dr. $H$. J. v. d. Schroeff ,Enige opmerkingen over mogelijkheden en wenselijkheden van een verbijzondering in de uitoefening van het accountantsberoep", in welk artikel werd gewezen op het zogenaamde collisiegevaar.

$\mathrm{Na}$ deze inleiding moge ik nu achtereenvolgens geven de reeds in de aanvang van dit artikel genoemde probleemstelling en de beantwoording van de daarin gestelde vragen. De enigszins uitvoerige inleiding maakt het m.i. mogelijk de beantwoording relatief kort te houden en van een uitvoerige motivering af te zien.

\section{B. Probleemstelling.}

I. Aard van de diensten, die de leiding van een kleine onderneming van de accountant verwacht, te onderscheiden naar:

a. contrôle

b. adviezen

c. assistentie bij de administratie

In hoeverre bestaat er ten aanzien van de aard en de omvang der gevraagde diensten verschil met de middelgrote en grote ondernemingen?

II. Is een opdracht tot contrōle van de jaarrekening van een kleine onderneming aanvaardbaar?

a. Mag worden gesteld, dat, mede door de onvoldoende mogelijkheden van interne contrôle, de accountant veelal niet tot een goedkeurende verklaring betreffende de jaarrekening kan komen?

b. Indien a priori vaststaat, dat geen goedkeurende verklaring kan worden afgegeven, kan dan, in verband met de functie van de public-accountant, de opdracht tot contrōle van de jaarrekening van een kleine onderneming worden aanvaard?

III. Indien de vraag sub $2 \mathrm{~b}$ ontkennend wordt beantwoord, kan dan wel een algemene opdracht tot contrōle worden aanvaard?

IV. Bestaat er ten aanzien van de aard en omvang der voor de contrōle te verrichten werkzaamheden een essentieel verschil tussen de werkzaamheden ten behoeve van de kleine, middelgrote en grote ondernemingen? 
V. In hoeverre dreigt door de aard en de omvang der adviezen het gevaar dat de accountant van de kleine onderneming in het beheer wordt betrokken?

Hierbij mede te bezien de vraag, of, gegeven de onvolkomenheid in de leiding bij een kleine onderneming, verwacht moet worden dat de leiding in vele gevallen niet tot een eigen oordeel in staat is en het ontvangen advies zonder meer zal worden opgevolgd.

VI. Dreigt in verband met het voorgaande het gevaar dat bij de controlerende functie daardoor de onafhankelijkheid van het oordeel van de public-accountant in gedrang komt?

VII. Zijn er grenzen aan te geven ten aanzien van de aard en de omvang der door de public-accountants in de kleine onderneming te geven adviezen?

VIII. Hoever strekt de verantwoordelijkheid van de public-accountant zich uit, als hij assistentie verleent bij de administratie?

Deze assistentie kan o.a. betreffen het opstellen van de jaarrekeningen, van de winstoverzichten op korte termijn, van de bedrijfsbegrotingen en van calculaties, alsmede het bijwerken van onderdelen van de administratie.

\section{Beantwoording van de in de probleemstelling gestelde vragen.}

I. Aard en omvang der diensten, die de leiding van een kleine onderneming van de accountant verwacht, t.o.v. die bij middelgrote en grote ondernemingen.

\section{a. Contrôle:}

Bij de kleine onderneming zal slechts zelden een opdracht tot contrôle van de jaarrekening worden gegeven, met het doel een korte verklaring van de accountant op te nemen in de gepubliceerde jaarrekening. Daar de kleine onderneming veelal geen toegang heeft tot de eerstehands vermogensmarkt zal hieraan geen behoefte bestaan.

Een opdracht tot contrôle van de jaarrekening komt echter ook bij de kleine onderneming veelvuldig voor. De accountant zal hier primair optreden als vertrouwensman (controlerend en adviserend orgaan) van de bedrijfsleiding; in verband met de sub II en III gestelde vragen zij er hier echter reeds op gewezen, dat de accountant er rekening mede moet houden, dat zijn rapport ter inzage kan worden gegeven buiten de besloten kring van vooraf bekende personen, die in de leiding van het bedrijf zijn betrokken resp. direct belanghebbend zijn; de functie van vertrouwensman van het maatschappelijk verkeer dient dus mede in het oog te worden gehouden (zie verder sub II en III).

De doelstelling van de opdracht tot algemene contrôle kan verschillend zijn, n.1.:

1. het oordeel van de accountant terzake van de juistheid der jaarrekening:

2. als basis tot décharge voor het personeel;

3. ter doorlopende bewaking van de juistheid der administratie en van de aan de leider gegeven informaties;

4. teneinde de accountant in staat te stellen op korte termijn, gevraagd resp. ongevraagd, de bedrijfseconomische adviezen te geven, waaraan de leider behoefte heeft. 
Bij de kleine ondernemingen zal de sub 2 en 3 genoemde doelstelling relatief frequenter voorkomen dan bij middelgrote en grote bedrijven. Op te merken valt echter dat in verband met de verhouding tot de fiscus de doelstelling sub 1 genoemd veelal bij de kleine onderneming domineert.

\section{b. Adviezen:}

Indien een accountant een opdracht tot contrōle heeft aanvaard, zal hij m.i. in grotere mate adviezen moeten geven dan in het algemeen bij middelgrote en grote bedrijven nodig zal zijn. Ook de leider van de onderneming zal in veel grotere mate adviezen vragen dan bij grotere ondernemingen, die veelal beschikken over stafemployè's, waaronder bij de grote ondernemingen enkele deskundigen. Afzonderlijke opdrachten, waarbij in feite een bedrijfseconomisch advies wordt gevraagd, zullen juist bij de kleine ondernemingen frequent voorkomen. Enerzijds zal bij de kleine onderneming de behoefte aan adviezen groter zijn, anderzijds zullen vele leiders van kleine ondernemingen zich deze behoefte niet altijd realiseren, terwijl de kosten veelal remmend zullen werken.

\section{c. Assistentie administratie:}

T.a.v. de assistentie bij de administratie valt op te merken, dat ook bij middelgrote en grote ondernemingen incidenteel wel assistentie van de accountant kan worden gevraagd. Bij vele kleine ondernemingen zal ook wanneer een afzonderlijke administratieve kracht aanwezig is, deze veelal onvoldoende comptabel geschoold zijn om een bedrijfsbegroting, de jaarrekening of winstoverzichten op korte termijn op te stellen. Vanuit de onderneming bezien kan het economisch doelmatig zijn om de accountant te verzoeken t.d.a. continueel assistentie te verlenen, daar de kosten dan toch lager uitkomen, dan wanneer een voldoende administratief geschoolde employè zou moeten worden aangetrokken.

Of in de praktijk aan accountants wordt verzocht de administratie geheel of nagenoeg geheel te verzorgen is mij niet bekend.

II. Is een opdracht tot contrôle van de jaarrekening van een kleine onderneming aanvaardbaar?

a. Onder verwijzing naar de inleiding meen ik, dat er inderdaad een aantal ondernemingen zijn, waarvan in verband met de omvang en de aard van het bedrijf, a priori gesteld kan worden dat de accountant niet tot een goedkeurende verklaring kan komen. Deze heb ik per definitie aangeduid als ,kleine onderneming". De oorzaak ligt dus hierin, dat, uiteraard het economisch motief in aanmerking nemende, de interne contrōle niet dusdanig kan worden verbeterd, dat de leemten voor de accountant geen beletsel zullen vormen om tot een oordeel te komen resp. dat de leemten van die aard en omvang zijn, dat de accountant deze niet met eigen arbeid kan opvangen, zonder dat de kosten van de contrôle te hoog worden.

In de inleiding wees ik er reeds op dat het antwoord op de vraag of een bepaalde onderneming tot de groep van kleine ondernemingen behoort, waarvoor deze omstandigheid geldt, mede afhankelijk is van de aard van het bedrijf. Bij dienstverleningsbedrijven zal dit eerder het geval zijn dan bij industriële resp. handelsondernemingen, terwijl binnen de genoemde groepen uiteraard eveneens grote verschillen aanwezig zijn.

b. Indien a priori vaststaat, dat geen goedkeurende verklaring kan 
worden afgegeven kan, in verband met de functie van de publicaccountant, m.i. de opdracht tot contrôle van een jaarrekening niet worden aanvaard, daar het doel, hetwelk met deze opdracht wordt beoogd, n.l. het oordeel van een onafhankelijk deskundige, niet kan worden bereikt. De vraag of de verklaring al of niet mede bestemd is voor derden dan wel uitsluitend bestemd is voor een der leiders resp. een vooraf bekende groep van personen, is hier niet relevant, daar de accountant nimmer zekerheid kan verkrijgen dat zijn verklaring resp. het rapport, hetwelk mede een verklaring inhoudt, niet aan derden zal worden overhandigd. De vraag, die veelal wordt opgeworpen of in plaats van een goedkeurende verklaring een niet goedkeurende verklaring dan wel een negatieve verklaring kan worden afgegeven, is wel belangrijk voor de beantwoording der sub III genoemde vraag, doch niet voor de gevallen, waarin een opdracht wordt gegeven tot contrōle van de jaarrekening. De doelstelling van de opdracht wordt met een zogenaamde negatieve verklaring resp. niet goedkeurende verklaring in dit geval niet bereikt. De negatieve verklaring betekent, onverschillig welke redactie men kiest, materieel bezien, dat de accountant geen oordeel heeft.

III. Daar ik de vraag sub II-b ontkennend heb beantwoord, valt thans te onderzoeken of wel een algemene opdracht tot contrôle kan worden aanvaard.

Ik vrees dat, in nog sterkere mate dan reeds bij vraag II het geval was, de mening van de verschillende collega's over dit punt sterk uiteen zal lopen.

Een niet onbelangrijk aantal leden zal, onder verwijzing naar de leer van het gewekte vertrouwen, ook deze vraag ontkennend beantwoorden.

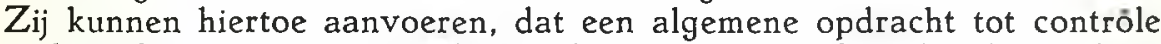
toch mede omvat een contrôle van de jaarrekening. Al zal wel geen korte verklaring onder de jaarrekening worden gevraagd, zo zal de accountant toch een rapport uitbrengen, waarin hij zijn oordeel, dus verklaring, opneemt. Hoe hij deze verklaring ook redigeert en beredeneert, en hoe hij ook zal trachten deze verklaring onbruikbaar te maken voor het maatschappelijk verkeer, zo zal dit rapport toch altijd bij derden groter vertrouwen opwekken dan gerechtvaardigd is door de verrichte arbeid. Noch een negatieve verklaring, noch een niet goedkeurende, noch een zogenaamd rapport van bevindingen kunnen in deze een uitweg bieden.

Hiertegenover verdedigen andere collega's naar mij gebleken is, een min of meer diametraal tegengesteld standpunt, waaraan men evenmin zonder meer voorbij kan gaan. Hun standpunt zou ik als volgt willen weergeven.

De kleine ondernemingen vertegenwoordigen tezamen, door hun grote aantal een groot maatschappelijk belang. Hun medewerking aan het maatschappelijk productieproces is noodzakelijk. Juist de kleine ondernemer, die over geen stafemployé's beschikt en die slechts zeer zelden voldoende kennis en ervaring heeft om, zelfstandig en zonder voorlichting een verantwoorde beslissing te nemen inzake de vele problemen, waarvoor hij dagelijks wordt gesteld, heeft behoefte aan de hulp en voorlichting van de accountant.

De accountant kan hier nuttig werk doen, o.a. bij de verbetering van de administratieve organisatie en de bewaking hiervan, en heeft als de vertegenwoordiger van een vrij beroep niet het recht zijn medewerking 
te weigeren. Echter slechts bij een regelmatige contrôle zal zijn werk tot het gewenste resultaat leiden.

Hoewel het in een aantal gevallen inderdaad niet mogelijk zal zijn tot een verklaring te komen terzake van de juistheid, is dit aantal gevallen veel kleiner dan veelal wordt aangenomen. Hierbij wordt dikwijls gewezen op de kleine industriële ondernemingen en de mogelijkheid van een verbandscontrôle. Ook wanneer niet tot een goedkeurende verklaring kan worden gekomen zal in vele gevallen het accountantsrapport voor de leider toch zijn volle betekenis houden. De beheersdaden worden toch bij de kleine onderneming grotendeels door de leider zelf gesteld. Het feit, dat geen goedkeurende verklaring naar buiten kan worden afgegeven. wordt gewoonlijk veroorzaakt door het feit, dat hij de getroffen maatregelen van interne contrôle incidenteel buiten werking kan stellen, en in staat is bepaalde beheersdaden (b.v. in - en verkoop; leningen, bewaarneming effecten enz.) buiten de administratie te houden. Wanneer uit het rapport van de accountant blijkt, dat geen fouten zijn geconstateerd, kan dit rapport voor de leider, die eventuele onjuistheden zelf weet, dus toch aan zijn doel beantwoorden. Het gevaar dat het rapport bij derden te groot vertrouwen opwekt, menen zij te kunnen ondervangen door de redactie van het rapport; daarbij wordt er op gewezen. dat deze derden veelal de fiscus resp. de bank zullen zijn, die beiden geacht kunnen worden de rapporten te kunnen lezen. Ook voor de rijksaccountants resp. inspecteurs kan de accountantscontrōle, ook al wordt geen goedkeurende verklaring afgegeven, toch van belang zijn als de wel gebleken fouten werden vermeld. De rijksaccountant kan dan volstaan met de aanvullende werkzaamheden voorzoverre hij over eigen contrōlemiddelen beschikt, die de accountant niet heeft.

Een nog verder gaand standpunt wordt soms verdedigd, met de opmerking, dat wanneer de accountant bij een contrôle heeft gedaan wat hij kan doen en op grond van deze contrôle en zijn vertrouwen in de eerlijkheid van de leider van het bedrijf voor zichzelf innerlijk overtuigd is van de juistheid van de jaarrekening, hij wel een goedkeurende verklaring kan afgeven.

Tegen de laatste opvatting meen ik zonder meer stelling te moeten nemen. Van de accountant wordt gevraagd een oordeel als deskundige terzake van de juistheid van de jaarrekening en geen oordeel over de persoon van de leider. Dat hij, ook wanneer hij geen goedkeurende verklaring geeft, toch de volle verantwoordelijkheid blijft dragen voor de wijze waarop hij de door hem aanvaarde functie heeft vervuld, behoeft evenmin nader betoog.

Een bespreking van de verschillende wederzijds genoemde argumenten zou mij te ver voeren.

Ik moge volstaan met mijn eigen mening summier weer te geven, zonder deze verder met argumenten te staven.

Ik acht onder bepaalde omstandigheden het aanvaarden van een algemene opdracht tot contrôle, ook indien a priori vaststaat dat geen goedkeurende verklaring kan worden afgegeven, mogelijk als:

1. tevoren ook voor de bedrijfsleider duidelijk vaststaat, dat geen goedkeurende verklaring terzake van de jaarrekening kan worden afgegeven.

2. de onderneming van voldoende importantie is, dat inderdaad de deskundigheid van een accountant voor de vervulling van deze functie gewenst is. 
3. dat de administratieve organisatie, in aanmerking nemende het economisch motief, aan de daaraan redelijkerwijs te stellen eisen voldoet, resp. verwacht mag worden dat de noodzakelijke verbeteringen worden doorgevoerd.

4. het doel, hetwelk de opdrachtgever wel voor ogen staat, nog rationeel moet worden geacht en kan worden verwezenlijkt.

5. op de verantwoording terzake van de door het personeel vervulde bewarings- en beheersfuncties, zo nodig met inschakeling van de leider resp. commissarissen, een contrôle mogelijk is, die een basis voor de décharge kan verschaffen.

6. de redactie van het rapport dusdanig kan worden gekozen dat dit rapport bij derden, aan wie het eventueel ter lezing wordt gegeven, geen te groot vertrouwen wekt. De opdrachtgever zal zich dus vooraf moeten realiseren, dat dit rapport t.o.v. derden slechts relatieve betekenis zal hebben.

T.a.v. de vraag of inderdaad aan deze eisen kan worden voldaan, dubieer ik t.a.v. punt 6; t.d.a. zal een discussie misschien verhelderend kunnen werken.

Als voorbeeld van ondernemingen, waarbij al bij voorbaat vaststaat, dat geen goedkeurende verklaring kan worden bereikt, die van voldoende importantie zijn, en waar de volle deskundigheid van accountant vereist is, denk ik aan commissionnairs in effecten, kleine bankbedrijven met één directeur, enz. Als voorbeeld van kleine ondernemingen, waar de algemene opdracht tot contrōle aan een accountant in het algemeen irrationeel moet worden beschouwd, denk ik aan de zeer kleine ambachtsbedrijven en de kleine, één-persoons-winkelzaken.

Buiten beschouwing heb ik gelaten de vraag, in hoeverre de accountant die tegenover derden optreedt als pleitbezorger van de belangen van de cliënt een te groot vertrouwen wekt resp. het gevaar loopt, dat zijn objectiviteit in twijfel zal worden getrokken. Als algemene waarschuwing dat toch niet te vlug op grond van het nut tot aanvaarding van een hierbedoelde opdracht moet worden overgegaan, moge ik ex wel op wijzen, dat het gevaar dat ook bij andere opdrachten de verklaring van de accountant minder vertrouwen gaat wekken en dus de werkelijke norm onder de rationele norm komt te liggen, niet geheel denkbeeldig is.

Uit het bovenstaande volgt, dat ik weliswaar niet geheel afwijzend sta tegen de aanvaarding van de hier bedoelde opdrachten, doch wel meen dat grote voorzichtigheid geboden is en dat het zeker gewenst is, dat over dit probleem nader van gedachten wordt gewisseld.

IV. Bestaat er ten aanzien van de aard en omvang der voor de contrôle te verrichten werkzaamheden een essentieel verschil tussen de werkzaamheden ten behoeve van de kleine, middelgrote en grote ondernemingen?

Zowel voor de kleine, middelgrote en grote ondernemingen geldt dat de contrôle volkomen moet zijn en dat de te verrichten werkzaamheden zullen verschillen naar de aard der opdracht en de aard van het bedrijf. Waar bovendien in principe de te hanteren contrôlemiddelen dezelfde zijn, kan hier m.i. niet van essentiële verschillen worden gesproken.

De aard van het bedrijf zal veelal groter invloed hebben op de te hanteren contrōlemiddelen dan de omvang van het bedrijf. Toch zullen 
de verschillen ontstaan door de omvang van het bedrijf zich niet uitsluitend beperken tot een verschil in techniek bij de hantering der contrôlemiddelen. Zowel het kleine als het grote bedrijf stelt zijn eigen eisen, en verlangt van de accountant een grote ervaring op dit terrein.

Hieronder heb ik getracht enige verschillen, uiteraard algemeen geformuleerd en niet uitputtend, aan te geven. Vooraf moge ik opmerken. dat bij de onderscheiding naar kleine, middelgrote en grote bedrijven geen scherpe grenzen aangegeven kunnen worden.

\section{De verschillen betreffen:}

a. Door de aard en de omvang der niet te ondervangen leemten en onvolkomenheden in de interne contrōle, zullen bij de kleine onderneming in veel grotere mate aanvullende werkzaamheden moeten plaats vinden. Veelal zal ook een deel van de accuratesse-contrôle, die normaal door het personeel geschiedt, moeten worden verricht.

b. Bij de Handels- en Industriële ondernemingen zal de administratie bij de kleine ondernemingen slechts zelden dusdanig zijn, dat het verband goederen-geldbeweging ook in totalen blijkt. De voorwaarden voor een totaal-contrôle, b.v. die op de verkopen zijn in principe niet vervuld. Dit brengt mede, dat de accountant, hetzij het verband in details moet nagaan (hetgeen dikwijls de contrôle uit kostenoogpunt onverantwoord zal maken), hetzij door eigen arbeid (specificatie inkopen naar artikel resp. bij industriële onderneming specificatie van de verkopen naar artikel, berekenen standaardverbruik enz.) zal trachten alsnog in totalen het verband te constateren. Volledigheidshalve wijs ik er nogmaals op, dat bij de kleine onderneming het bezwaar van de leemten en onvolkomenheden in de interne contrôle, die niet door eigen werkzaamheden kunnen worden opgevangen, blijft bestaan. Eveneens wijs ik er op, dat zelfs waar standaardcalculaties en bedrijfsbegroting zijn opgesteld, de daarin opgenomen normen veelal zullen zijn aangegeven door de leider van het bedrijf, die zelf zowel de beheersdaden stelt als in de uitvoering is betrokken. Waar bewaring, beheer en administratie voor een groot gedeelte in één hand liggen, kunnen ook indien vorenbedoelde werkzaamheden mogelijk zijn en geen fouten aan het licht brengen, deze toch niet tot een goedkeurende verklaring voeren.

c. Bij de kleine onderneming $z$ al de contrôle zich veelal niet uitsluitend op de contrōle van de jaarrekening richten.

Bij de niet te vermijden leemten in de administratieve organisatie, waaronder dus ook de interne contrôle valt, zal veelal ook in de loop van het jaar de juistheid van bepaalde onderdelen van de administratie (b.v. die waaruit de vermogensrechtelijke betrekkingen met derden blijken) moeten worden nagegaan. Ook wanneer dit door de opdrachtgever niet uitdrukkelijk is bepaald, zal rekening moeten worden gehouden met de waarschijnlijkheid dat de opdrachtgever dit verwacht.

Daar juist bij kleine ondernemingen het gevaar dreigt dat in de accountant een overdreven vertrouwen wordt gesteld, waaraan de accountant, o.a. in verband met rationele kostenoverwegingen, niet kan voldoen, is het gewenst de opdrachtgever vooraf duidelijk te maken dat onjuistheden in de administratie (b.v. in de debiteurenadministratie) niet alle tijdig tijdens de contrôleperiode zullen worden gesignaleerd. 
d. Beperkingen op grond van het relatief geringe belang zullen minder frequent mogelijk zijn.

De steekproeven, voorzoverre deze een toepassingsmogelijkheid vinden, zullen bij de kleine onderneming veelal een relatief groter aantal posten moeten bevatten en kunnen naar de $100 \%$ tenderen.

De volkomen contrōle zal bij de kleine ondernemingen dichter bij de zogenaamde volledige contrôle komen te liggen dan bij de grotere ondernemingen het geval is.

e. Ook t.a.v. de contrôletechniek zijn m.i. graduele verschillen te constateren. Daar deze moeilijk zijn aan te geven zonder in een casuistiek te vervallen, moge ik t.d.a. met deze algemene opmerking volstaan.

V. In hoeverre dreigt door de aard en de omvang der adviezen het gevaar dat de accountant in het beheer wordt betrokken?

Bij de aard der adviezen valt primair te onderscheiden naar de adviezen, die uitsluitend voor de leider van het bedrijf van belang zijn en die welke ook voor - al of niet vooraf bekende - derden bestemd zijn. De laatstbedoelde adviezen (b.v. bij koop of verkoop van een bedrijf. regelingen met crediteuren enz.) zal ik onbesproken laten.

T.a.v. de adviezen ten behoeve van de leider van het bedrijf merk ik op, dat uit de contrôlefunctie voortvloeit, dat door de accountant mondeling of schriftelijk opmerkingen worden gemaakt, die, zoal niet uitdrukkelijk als zodanig bedoeld, het karakter van advies verkrijgen. Bij de kleine ondernemingen zullen deze adviezen zeker veelvuldiger voorkomen.

Bij deze ondernemingen zullen de hier bedoelde opmerkingen veelal niet algemeen kunnen worden gesteld, doch zullen in grotere mate concreet gericht moeten zijn.

Het gevaar dreigt ongetwijfeld, dat de accountant zich niet beperkt tot de aspecten van de problemen, ten aanzien waarvan hij deskundig is, doch bewust of onbewust, indirect ook andere aspecten (technische en commerciële) in zijn advies betrekt. Hij zal hiertoe des te meer neigen, naar mate hij de overtuiging heeft, dat de leider van het bedrijf, (gegeven zijn kennis en ervaring) minder in staat is zelf de problemen te bezien en zelf een verantwoorde beslissing te nemen. Door bedoelde onvolkomenheden in de leiding zal, overigens mede afhankelijk van het vertrouwen dat de leider in de accountant stelt, het gevaar groter worden, dat hij zonder meer het advies van de accountant opvolgt; dit gevaar is latent altijd aanwezig, daar de leider van de kleine onderneming de steun van stafemployé's mist en het dikwijls economisch niet mogelijk zal zijn t.o.v. de problemen resp. aspecten van de problemen, waarop de accountant niet specifiek deskundig is, adviezen van andere deskundigen in te winnen. Hoewel formeel het beheer bij de leider van de onderneming blijft berusten, gaat dit materieel bezien voor een deel over op de accountant; zelfs wanneer door persoonlijke kwaliteiten de accountant de capaciteiten zou hebben om de onderneming te leiden, hetgeen slechts zelden het geval zal zijn, blijft dit m.i. in strijd met zijn functie als accountant.

Voor de adviezen, welke de bedrijfsleider aan de accountant, die de onderneming controleert, vraagt resp. die waarvoor hij een afzonderlijke opdracht aan een accountant geeft, mag ik verwijzen naar de opmerkingen sub C-I. T.a.v. de vraag in hoeverre de aard der hier be- 
doelde adviezen bij de kleine onderneming verschilt t.a.v. die bij de grotere ondernemingen, valt op te merken dat de kans, dat de accountant adviezen worden gevraagd op een terrein, waarop hij niet of niet in hoofdzaak deskundig is, bij de kleine onderneming, die de accountant graag als "Manusje van alles" ziet, ongetwijfeld groter wordt.

Uit het bovenstaande volgt, dat m.i. het gevaar dat de accountant bij de kleine onderneming in het beheer wordt betrokken, zeker groter is dan bij middelgrote en grote ondernemingen. Ik wijs er echter, onder referte aan de inleiding op, dat als criterium voor de onderscheiding naar kleine, middelgrote en grote bedrijven voor dit probleem moet worden gekozen de onvolkomenheid in de leiding. Scherpe grenzen zijn hier niet te trekken. Wel kan gesteld worden, dat bij een kleine onderneming deze onvolkomenheid van nature gegeven is, doch onder de kleine ondernemingen volgens de door mij bij de inleiding gegeven definitie, komen ondernemingen voor van geheel verschillende importantie. De aard van het bedrijf speelt hierbij een grote rol. De directeur van een kleine bank zal t.a.v. de bedrijfseconomische problemen minder tekort schieten, dan de leider van een middelgrote onderneming, die voornamelijk op technisch terrein kennis en ervaring heeft verworven.

VI. Dreigt in verband met het voorgaande het gevaar dat bij de controlerende functie daardoor de onafhankelijkheid van het oordeel van de accountant in gedrang komt?

Voor de beantwoording van deze vraag mag ik primair verwijzen naar het in de inleiding reeds gememoreerde artikel van Prof. v. d. Schroeff (october 1947) benevens naar het desbetreffende artikel van Prof. A. M. van Rietschoten (februari 1948).

Het door Prof, v. d. Schroeff gesignaleerde gevaar is ongetwijfeld, wanneer we de adviezen die uitsluitend betrekking hebben op de administratieve organisatie uitschakelen, groter naar gelang de leider van het bedrijf minder in staat is, om, na kennisneming van het advies, het probleem te overzien en geneigd is zonder meer dit advies op te volgen.

Ik wijs er echter op, dat hoewel bij kleine ondernemingen dit zogenaamde collisiegevaar toeneemt en dus uit dien hoofde een differentiatie tussen de adviserende en controlerende functie gewenst wordt, anderzijds juist bij de kleine ondernemingen de samenhang tussen controlerende en adviserende functie veelal een noodzaak wordt. Het aantrekken van twee of meer afzonderlijke externe deskundigen zal voor het kleine bedrijf veelal te hoge kosten medebrengen.

VII. Zijn er grenzen aan te geven ten aanzien van de aard en omvang der door de public-accountant te geven adviezen?

M.i. zal de individuele accountant voor elk concreet geval zich moeten afvragen hoeverre hij mag en moet gaan t.a.v. de door hem te geven adviezen. Van het gevaar, dat hij uiteindelijk in het beheer wordt betrokken en in het extreme geval de feitelijke leider van de onderneming zal worden, zal hij zich steeds bewust moeten zijn. Omgekeerd bestaat juist bij de kleine ondernemer een grote behoefte aan deze adviezen, in welke behoefte dikwijls niet op andere wijze kan worden voorzien. Indien de wijze waarop de functie in de kleine onderneming wordt vervuld, geen invloed zou hebben op het vertrouwen, dat men in groter verband stelt in het onafhankelijke oordeel van de accountant, zou men. zij het ook enigszins eenzijdig, kunnen stellen dat zowel algemeen eco- 
nomisch bezien als vanuit het standpunt van de leider der kleine ondernemingen, de adviserende functie van de accountant primair moet worden geacht en de controlerende functie voor de kleine onderneming juist voornamelijk van belang is om de adviserende functie naar behoren te kunnen vervullen.

Mijn persoonlijke mening zou ik als volgt willen formuleren:

a. Indien de accountant heeft besloten de contrōle van een kleine onderneming te aanvaarden, zal zijn functie medebrengen het geven van adviezen.

b. Tot de adviezen welke van hem mogen worden verwacht en waartegen geen bezwaar bestaat, behoren die op het terrein van de administratieve organisatie.

c. Concrete adviezen op ander terrein dient hij alleen te geven, voorzoverre hij alle aspecten van het probleem kan overzien en deze liggen op het terrein, waarop hij deskundig is.

d. Voorzoverre hij naar aanleiding van zijn contrōle opmerkingen wenst te maken, welke het karakter van een advies kunnen aannemen dient hij deze voorzoverre ze niet onder de sub b en $c$ genoemde vallen, te geven in de vorm van een probleemstelling, die door de leider dient te worden bezien. Aanbeveling verdient het dit probleem met de leider van de onderneming te bespreken en zo objectief mogelijk alle aspecten te belichten, die de accountant ziet. Zoveel mogelijk dient de leider in staat te worden gesteld zichzelf een oordeel te vormen. Hier ligt m.i. bij de kleine onderneming voor de accountant een opvoedende taak.

VIII. Hoever strekt de verantwoordelijkheid van de public-accountant zich uit als hij assistentie verleent bij de administratie?

Buiten beschouwing zal ik laten de mogelijkheid dat een public-accountant een gedeelte van de administratie verzorgt, zonder tevens een algemene opdracht tot contrôle te hebben ontvangen. In die gevallen zou de accountant bij de desbetreffende onderneming de functie van boekhouder vervullen. Wel rijst dan de vraag in hoeverre de vervulling van laatstgenoemde functie door een persoon, die tevens deskundig is op het terrein van de leer van de contróle, invloed moet hebben op de wijze, waarop hij die functie vervult en de complicatie doordat dezelfde persoon tevens in andere specifieke functies als public-accountant optreedt. Bij de kleine onderneming zal ongetwijfeld de algemene functie van public-accountant domineren en zal een dusdanige opdracht zeker niet aanvaardbaar zijn los van een opdracht tot algemene contrôle.

Daar voor de vervulling van de taak van een boekhouder zeker niet de kennis en bekwaamheid van een accountant nodig is, is deze com binatie van functies m.i. economisch gezien veelal irrationeel. Voor de vaktechnische bezwaren tegen de combinatie van functies verwijs ik naar het onderstaande.

Voor zover van de public-accountant, die een contrôle-opdracht heeft aanvaard, op meer beperkte schaal assistentie wordt gevraagd, valt te onderscheiden naar:

a. incidentele assistentie

b. continuele assistentie

Algemeen economisch en van de kant van de ondernemer bezien kan het vragen van de assistentie hier wel rationeel worden geacht, voor- 
zoverre deze assistentie minder kosten medebrengt dan een anders noodzakelijke personeelsuitbreiding resp. aanstelling van een relatief dure kracht, voor wie geen volle dagtaak zou zijn.

De bezwaren tegen het verlenen van assistentie zijn:

a. De combinatie van de administratieve en controlerende functie; de accountant controleert dan of zijn eigen werk of dat van zijn personeel.

b. De verantwoordelijkheid van de accountant voor de door hem resp. zijn assistenten verrichte werkzaamheden is moeilijk af te grenzen. Enerzijds vervult hij in feite voor dit gedeelte de functie van boekhouder, anderzijds wordt in de door hem (resp. zijn assistenten) opgestelde cijfers en overzichten een groter vertrouwen gesteld, daar zij van een accountant afkomstig zijn.

c. Voorzoverre overzichten worden getypt op papier waarop de naam van de accountant resp. zijn kantoor voorkomt, kan hij in strijd komen met art. 13 van het reglement van Arbeid, indien en voorzoverre de juistheid van de bedoelde overzichten niet voldoende vaststaat. Dit zal veelal het geval zijn, als hij zijn contrôlewerkzaamheden nog niet beëindigd heeft, resp. ook het systematisch geheel der verrichte contrôlewerkzaamheden onvoldoende zekerheid vermag te bieden.

Indien de overzichten op blanco papier worden verstrekt is formeel genoemd art. 13 R.v.A. niet van toepassing; het bezwaar sub b blijft echter gelden. Ik wijs er nog op, dat voorzover overzichten op blanco papier worden getypt, het bezwaar van een te groot vertrouwen m.i. alleen de accountant kan worden tegengeworpen, als dit ontstaat bij degeen, aan wie de overzichten worden overhandigd. Derden dienen aan niet ondertekende staten geen meerder vertrouwen te schenken op grond van een mededeling of een vermoeden, dat ze van de accountant afkomstig zijn. Het is m.i. rationeler uit een staat, waarop geen naam van de accountant voorkomt, af te leiden dat de accountant zich hiervan distancieert dan hieruit te concluderen tot een goedkeurende verklaring. Art. 13 R.v.A., hetwelk m.i. toch reeds een gevaarlijk artikel is, hetwelk zijn doel voorbij schiet, is hier zeker niet van toepassing.

Concluderend vermeld $\mathrm{ik}$, dat het ongetwijfeld gewenst is, dat de public accountant het verlenen van assistentie zoveel mogelijk nalaat. Nadat valt echter te bezien in welke gevallen het verlenen van assistentie onvermijdelijk is resp. tolereerbaar kan worden geacht; tevens valt na te gaan op welke wijze de genoemde bezwaren kunnen worden ondervangen resp. tot een nog aanvaardbaar minimum kunnen worden teruggebracht.

Ik vermeld t.d.a.:

\section{Incidentele assistentie.}

Dit kan betreffen:

a. Tijdelijke assistentie ter instructie van het personeel, o.a. bij een wijziging in de administratie.

Voorbeelden: bedrijfsbegroting, winstoverzichten en calculaties.

b. tijdelijke assistentie bij incidenteel grote drukte bij de cliënt resp. tijdelijke vervanging van een functionaris, bij ziekte of ontslag.

M.i. zal deze assistentie moeilijk kunnen worden geweigerd. 
In het merendeel der gevallen kunnen de bezwaren ondervangen worden door een assistent uit te lenen en de cliënt er uitdrukkelijk op te wijzen, dat deze assistent tijdelijk moet worden beschouwd als personeel van de cliënt, en de hem opgedragen werkzaamheden buiten verantwoordelijkheid van de accountant zullen vallen. De desbetreffende assistent dient dan niet te worden ingeschakeld in de contrôle over de periode, waarover hij assistentie heeft verleend.

Werkt de accountant zonder assistenten en is vorenstaande oplossing dus uitgesloten, dan zal hij zoveel mogelijk de door hem opgestelde cijfers direct moeten controleren en duidelijk moeten laten uitkomen, in hoeverre hij voor de geproduceerde cijfers wel of geen verantwoordelijkheid kan aanvaarden.

\section{Continuele assistentie,}

Hoewel het voor de kleine onderneming rationeel kan zijn die onderdelen van de administratie, waarvoor zijn personeel niet de vereiste comptabele kennis bezit, te laten bijhouden door de accountant, is het m.i. de vraag of dit van de zijde van de accountant toch niet in vele gevallen irrationeel moet worden geacht. Meestal zal door aanstelling van een avondboekhouder of door het opdragen van deze werkzaamheden aan een administratiekantoor een betere oplossing mogelijk zijn. Mede met het oog op jonge accountants, die zich pas gevestigd hebben, is een verbodsbepaling m.i. echter niet gewenst.

Voorzoverre afzonderlijke assistenten, die niet bij de contrōle worden ingeschakeld, met deze assistentie kunnen worden belast, zouden de bezwaren ten dele worden ondervangen. Veelal is deze oplossing echter niet goed mogelijk.

T.a.v. het opmaken van de jaarrekening kunnen de bezwaren tot een minimum worden teruggebracht, als deze niet aan de cliënt wordt overhandigd, voordat alle contrōlewerkzaamheden zijn verricht. Ook art. 13 van het Reglement van Arbeid behoeft hier geen moeilijkheden te bieden.

T.a.v. het verlenen van assistentie bij het opstellen van begrotingen, winstoverzichten en calculaties enz. verwijs ik naar mijn opmerkingen sub ,incidentele assistentie", laatste alinea.

Ik meen met het bovenstaande voldoende stof te hebben gegeven tot een discussie over de vele interessante vraagstukken, welke bij het onderwerp "de accountant en de kleine onderneming" aan de orde dienen te worden gesteld.

\section{SUMMARY}

After some introductory remarks, in which the problems are stated which arise out of any engagement for the accountant the question is reviewed according to what criteria, in the scope of this article, the classification according to small, medium sized and big enterprises will have to be made. Number of workmen, size of capital, amount of wages 